\title{
Minerály řady ullmannit - gersdorffit $v$ asociaci s milleritem z haldy dolu Lill v Př́brami (Česká republika)
}

\author{
Minerals of the ullmannite-gersdorffite solid-solution in association with millerite \\ from the mine dump of the Lill mine, Príbram (Czech Republic)
}

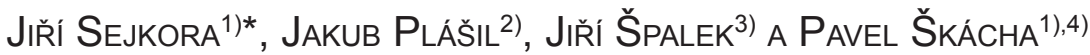 \\ 1)Mineralogicko-petrologické oddělení, Národní muzeum, Cirkusová 1740, 19300 Praha 9; \\ ${ }^{*}$ e-mail: jiri.sejkora@nm.cz \\ 2)Fyzikální ústav Akademie věd ČR, v.v.i., Na Slovance 2, 18221 Praha 8 \\ ${ }^{3}$ Karlovarská 458, 27364 Doksy \\ 4)Hornické muzeum Přibram, nám. Hynka Kličky 293, 26101 Přibram VI
}

SEJKora J, PLÁŠIL J, Špalek J, ŠKÁCHA P (2020) Minerály řady ullmannit - gersdorffit v asociaci s milleritem z haldy dolu Lill v Př́brami (Česká republika). Bull Mineral Petrolog 28(1): 203-209 ISSN 2570-7337

\begin{abstract}
Minerals of the ullmannite-gersdorffite solid-solution was found at mine dump material from the Lill mine, the Černojamské ore deposit, Príbram, central Bohemia, Czech Republic. It forms grey groups of idiomorphic crystals up to 0.5 $\mathrm{mm}$ across with metallic luster on millerite crystals. It is strongly chemically zoned, from As-rich ullmannite to gersdorffite with variable Sb contents. Its unit-cell parameter, a 5.7728(13) $\AA$ and $V$ 192.37(7) $\AA^{3}$, was refined from single-crystal $\mathrm{X}$-ray data. Groups of acicular millerite crystals up to $4 \mathrm{~mm}$ in length with formula $\left(\mathrm{Ni}_{0.97} \mathrm{Co}_{0.03}\right)_{\Sigma 1.00} \mathrm{~S}_{1.01}$ and very rare siegenite grains up to $80 \mu \mathrm{m}$ with formula $\mathrm{Co}_{1.00}\left(\mathrm{Ni}_{1.66} \mathrm{Co}_{0.24} \mathrm{Fe}_{0.02}\right)_{\Sigma 1.92} \mathrm{~S}_{4.09}$ were found in association.
\end{abstract}

Key words: ullmannite, gersdorffite, millerite, chemical composition, Lill mine, Príbram, Czech Republic

Obdrženo 20. 4. 2020; prijato 5. 6. 2020

\section{Úvod}

Bývalý důl Lill lokalizovaný v současné průmyslové zóně na sz. okraji města Příbram byl hlavním důlním dílem, z kterého bylo těženo a zkoumáno černojamské ložisko, součást březohorského rudního revíru. Halda dolu Lill byla od ukončení posledního geologického průzkumu na uranové rudy $v$ roce 1965 opakovaně $v$ několika etapách odtěžována a rozvážena (nejintenzivněji v letech 1990 - 2001), posléze aplanována a v současné době je zastavěna výrobními objekty. $V$ roce 2000 byla část haldového materiálu převezena do areálu nedaleké šachty Ševčín pro exkurzní účely (součást objektů Hornického muzea Př́bram). Studovaný vzorek byl v roce 2018 nalezen (JŠ) právě v této redeponované části odvalu.

Důl Lill patří mezi nejvýznamnější příbramské lokality. Byla zde popsána celá řada minerálů $v$ několika souhrnných pracích (například Babánek et al. 1875) a celé řadě krátkých příspěvků $v$ tehdy rakousko-uherských montánně-prírodovědných časopisech (jejich přehled publikován v práci Škáchy, Plášila 2002). Nověji byly zpracovávány haldové nálezy z období rekultivace haldy dolu Lill, kdy bylo nalezeno značné množství ukázek různých paragenetických typů mineralizace, jejichž výzkum není dosud dokončen. Ve formě neobvyklých paprsčitých agregátů byl nalezen magnetit (Litochleb et al. 2004). Minerál blízký andoritu byl nalezen $v$ asociaci s diaforitem, freieslebenitem, miargyritem a semseyitem (Plášil et al. 2005). Dále byl popsán ojedinělý výskyt makroskopického semseyitu (Plášil et al. 2007), siegenit a heazlewoodit v asociaci s milleritem (Plášil et al. 2009a) a imiterit v asociaci se stefanitem (Plášil et al. 2009b). Byly zjištěny i zajímavé supergenní minerály, vzácný munakatait obsahující selen (Sejkora et al. 2010) a dva nové minerální druhy - znucalit (Ondruš et al. 1990) a bouškait (Sejkora et al. 2019).

\section{Historie těžby v oblasti dolu Lill}

V oblasti dolu Lill byly zjištěny přípovrchové staré práce, jejich datace je ale problematická. Snad je možné jejich vznik spojit s 16 . stoletím, kdy byla nejen v príbramské oblasti rozsáhlá hornická aktivita. $V$ tomto století byly na černojamských vrších zmiňovány Černojamské doly, které by mohly odpovídat dnešním stařinám na Horní Černojamské žíle a v jejím okolí. V 19. století, kdy již existuje dostatek písemných pramenů, byla založena jáma Lill jako poslední z dolů Černojamského ložiska $v$ roce 1857. Ještě předtím však byly zpřístupněny stařiny na Černojamské štole (dnešní úroveň 1. patra) v roce 1821, kde se prováděl průzkum a přiležitostná těžba na Horní a Dolní Černojamské žíle až do roku 1826. Založení jámy také předcházel podrobný př́povrchový průzkum šachticemi, které ověřily směr a rozsah některých žil. Po založení jámy Lill došlo na přelomu 70. a 80. let 19. století k jejímu spojení s šachtou Jarošovka na úrovni 5. patra. Započalo se s dobýváním na Horní Černojamské žíle (od povrchu) a později ještě na stříbrné minerály bohaté 2 . Ležaté žíle, která byla těžena pod 8. patrem. Průzkum a těžba prokázaly vazbu rudní mineralizace na bohaté, ale prostorově velmi omezené čočky, které nedávaly na- 

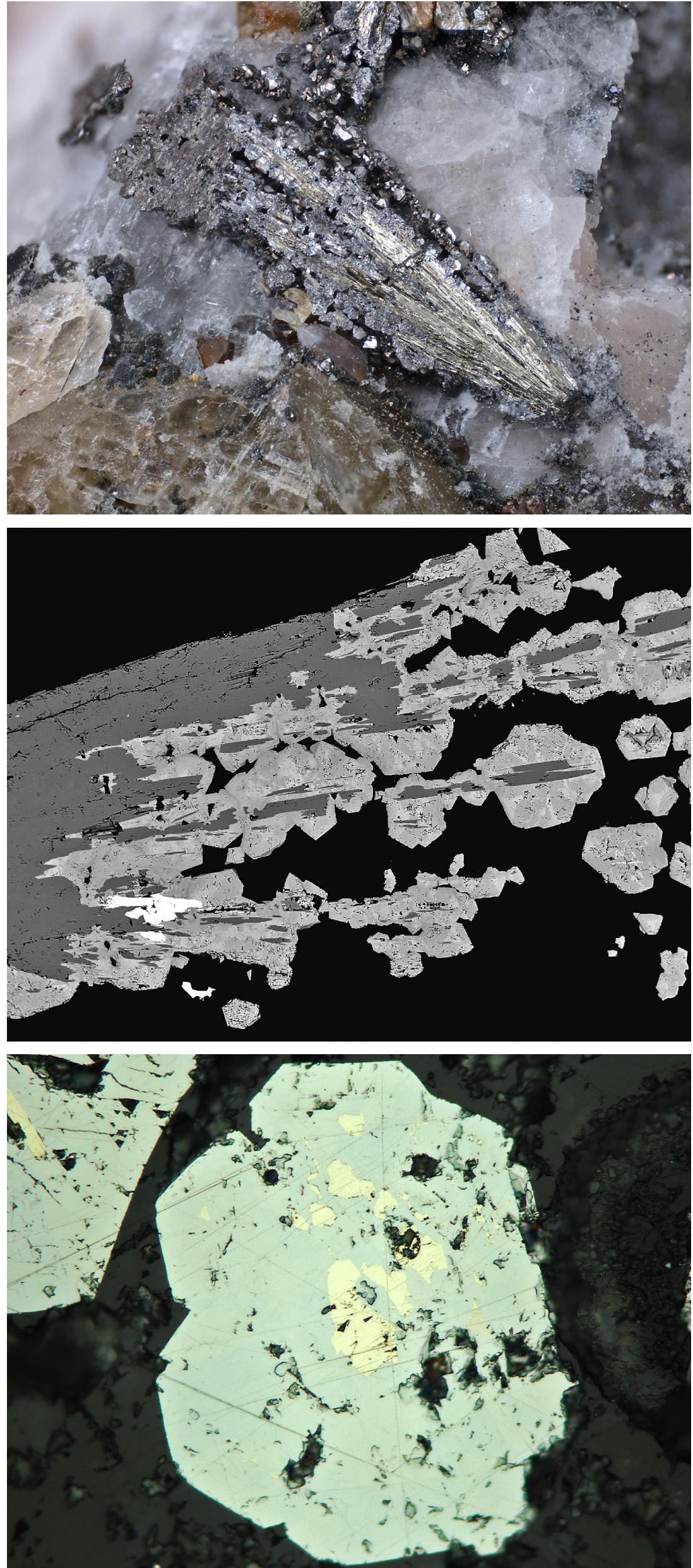

ději na rentabilitu těžby. Celkově ve směru do hloubky žilná výplň hluchla, a tak došlo $v$ roce $1902 \mathrm{k}$ uzavření a zatopení dolu Lill. V letech 1929 1933 byly žily Lillského dolu podfárány $z$ dolu Anna na úrovni 29. patra. Průzkum vykázal bilanční zrudnění na některých žilách, ale pro obtížné báňsko-technické podmínky byl tento projekt ukončen (Škubal, Janout 1965).

V roce 1947 byl při prvních pokusech o hledání uranových rud na Príbramsku navštíven nejprve odval dolu Lill, kde byly zjištěny hojné výskyty uraninitu. Halda byla kompletně ovzorkována a důl byl otevřen až do úrovně 5. patra, pro technické problémy a negativní výsledky však byl důl opět uzavřen. Naposledy se přikročilo k otvírce dolu Lill v letech 1961 - 1965, kdy se již podařilo prostor dolu vyčerpat až po nejnižší, 18. patro, byla vystrojena jáma a proběhl průzkum na uran a barevné kovy. Byl zjištěn vysoký stupeň vydobytí zrudnělých partií žíly a neperspektivní pokračování zrudnění do hloubky, proto byla $v$ roce 1965 jáma znovu uzavřena. $V$ letech 1956 - 1965 byl zkoumán prostor hlubokých partií lillských žil, tentokrát $z$ úrovně 35 . patra dolu Anna. Toto ověření však již ukázalo nepatrný rozsah zrudnění a další výzkum hlubokých partií lillského žilného systému nebyl realizován (Škubal, Janout 1965).

Obr. 1 Jehlicovité krystaly milleritu (o délce do $4 \mathrm{~mm}$ ) částečně zatlačované minerály řady ullmannit - gersdorffit; častečně odleptaný vzorek; sbírky Hornického muzea Přibram; foto P. Škácha.

Obr. 2 Zonální skupiny krystalů minerálů raady ullmannit - gersdorffit (světlejši odstíny šedé) narůstající na jehlicovité krystaly milleritu (tmavě šedý) a ojedinělý agregát galenitu (bílý), šiřka záběru $2 \mathrm{~mm}$; BSE foto J. Sejkora.

Obr. 3 Srostlice izometrických krystalů minerálů rady ullmannit - gersdorffit s relikty žlutého milleritu, šírka záběru $300 \mu m$, foto $v$ odraženém světle (částečně zkřižené nikoly) J. Sejkora. 


\section{Charakteristika výskytu}

Důl Lill byl založen $v$ horninách svrchního proterozoika za tzv. jílovou rozsedlinou, která je hlavní tektonickou strukturou oblasti. Užší okolí dolu Lill $s$ doly Ferdinand a Jarošovka je součástí Černojamského ložiska, které patří z hlediska souhrnné těžby polymetalických kovů mezi méně významnou část březohorského rudního revíru (Škácha, Plášil 2002).

Proterozoikum tzv. 2. brridličného pásma patří do blovicko-tepelské série svrchního proterozoika tepelsko-barrandienské oblasti, kralupsko-zbraslavské skupiny. Horninové prostředí je tvořené velmi pestrým vulkanicko-sedimentárním souvrstvím. Z vulkanických hornin jsou hojně zastoupeny bazické vulkanity, zejména metabazalty a spility (ve formě příkrovů, pravých i ložních žil), lávy, tufy a tufity. I další sedimenty mají značnou vulkanogenní príměs. Nejhojnější sedimenty jsou grafitické a jiné břidlice, droby a prachovce. Vyskytují se i nepř́liš mocné polohy buližníků a také karbonátové horniny. $V$ celém diskutovaném prostoru dochází k velmi četnému a pestrému střídání jednotlivých hornin, na hlubších horizontech lze pozorovat přibývání vulkanogenního materiálu (Bambas 1990).

$\mathrm{V}$ prostoru dolu Lill bylo odkryto cca 14 rudních žil, nejvýznamnější z nich byla Horní Černojamská a 2 . Ležatá žíla. Na žilách bylo zjištěno několik mineralizačních stádií: sfaleritové, siderit-sulfidické, galenit-baryt-ankeritové, Mn-kalcit-pyritové, uraninitové a kalcit-barytové. Ni-Co minerály byly zjištěny při těžbě a průzkumu jak v 19. tak i ve 20. století. Millerit patří k nejobvyklejším Ni-Co minerálům na lokalitě, vyskytuje se převážně v dolomiticko-ankeritickém karbonátu. Asociuje s galenitem a sfaleritem. Druhý typ výskytu milleritu byl vázán na dutiny $v$ nikelínu, kde tvořil až přes $1 \mathrm{~cm}$ velké krystaly na drúzách tmavě zabarvených krystalů křemene (sbírky Hornického muzea Příbram) (Škubal, Janout 1965).

Obr. 5 Sektorově zonální skupina krystalů minerálů rady ullmannit gersdorffit (světlejši odstíny šedé) narůstající na jehlicovité krystaly milleritu (tmavě šedý), šířka záběru $400 \mu \mathrm{m}$; BSE foto J. Sejkora.

Obr. 6 Graf As vs. Sb (apfu) pro minerály rady ullmannit - gersdorffit.

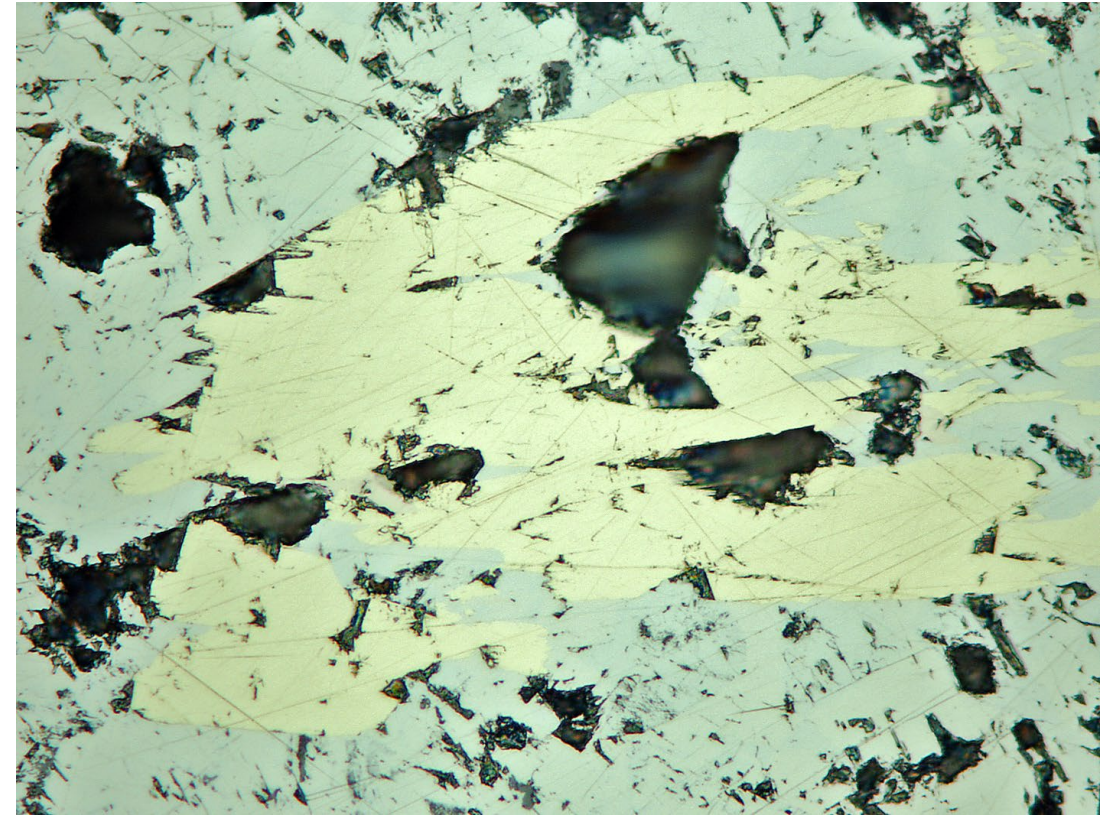

Obr. 4 Agregáty milleritu (žlutý) zatlačované členy rady ullmannit - gersdorffit, šířka záběru $300 \mu \mathrm{m}$, foto v odraženém světle (částečně zkřižené nikoly) J. Sejkora.
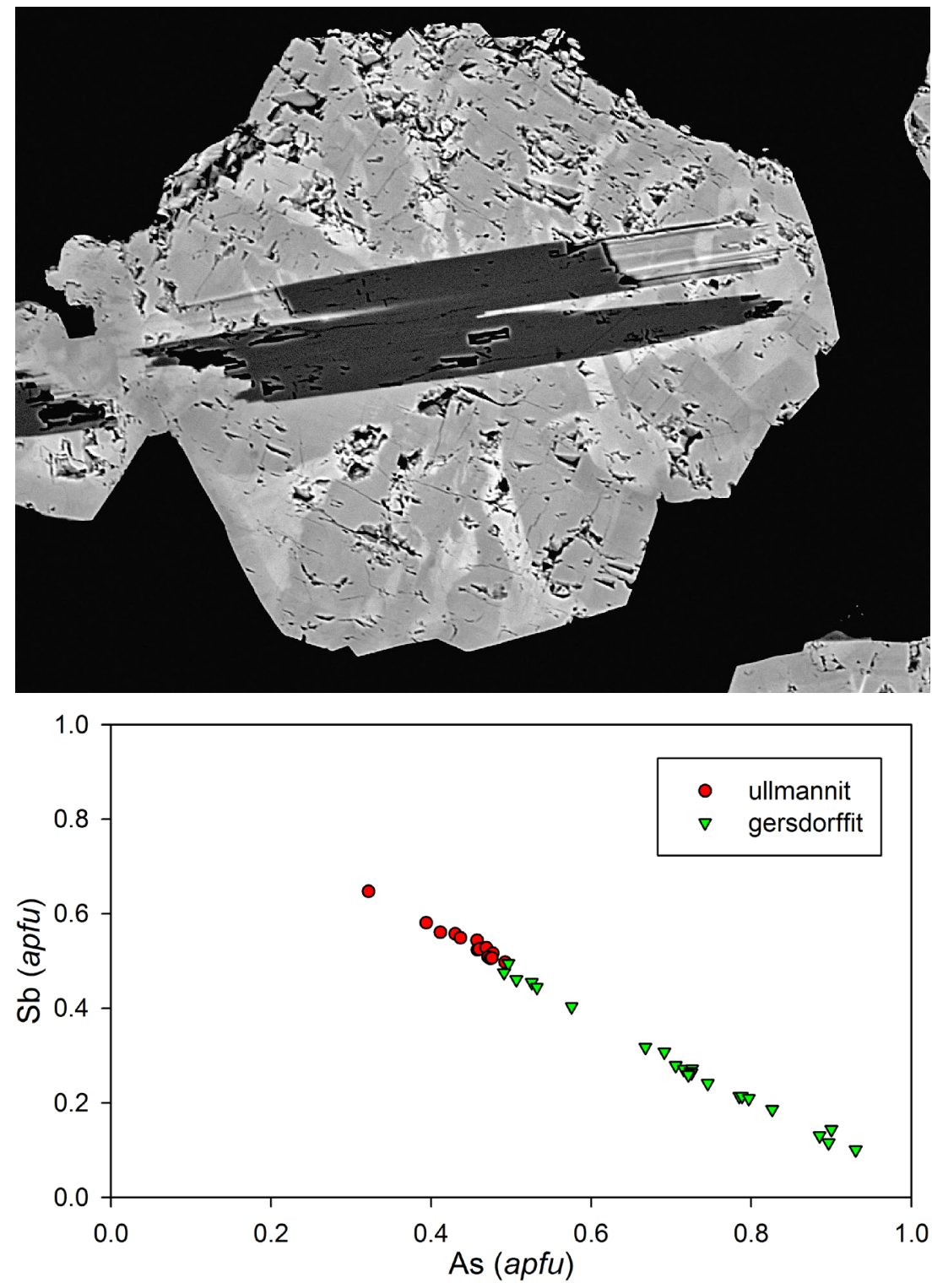


\section{Metodika výzkumu}

Nábrusy studovaných vzorků byly pro výzkum v odraženém světle a následné chemické analýzy připraveny standardním leštěním pomocí diamantové suspenze. Optické vlastnosti v odraženém světle byly studovány pomocí mikroskopu Nikon Eclipse ME600 s digitální kamerou

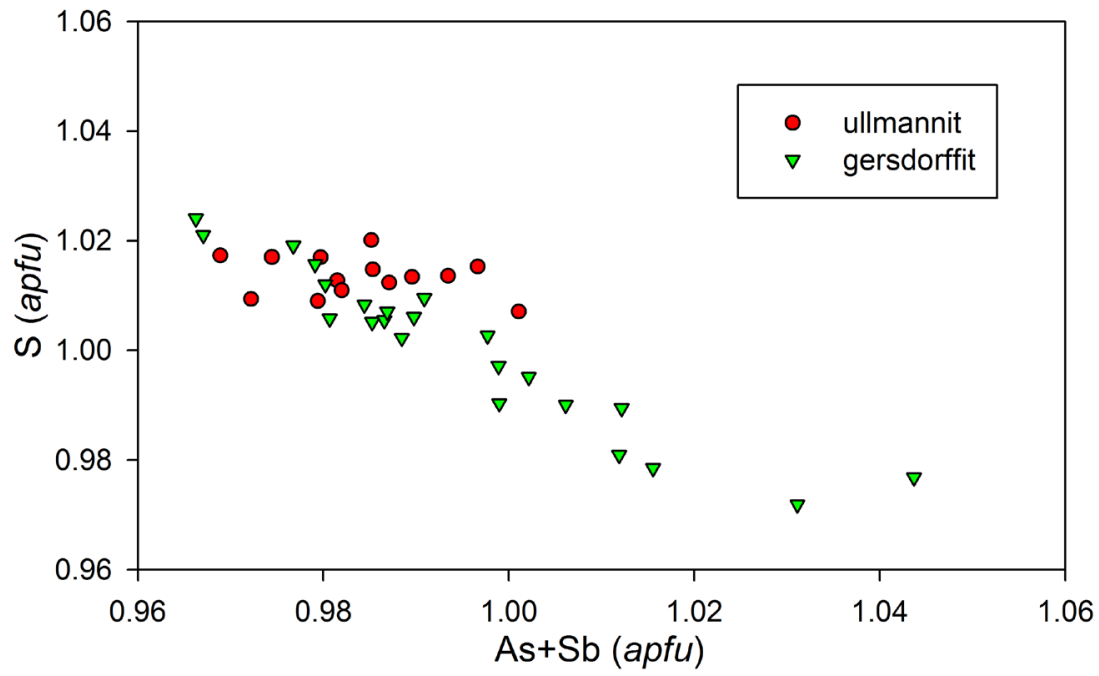

Obr. 7 Graf As+Sb vs. S (apfu) pro minerály řady ullmannit - gersdorffit.

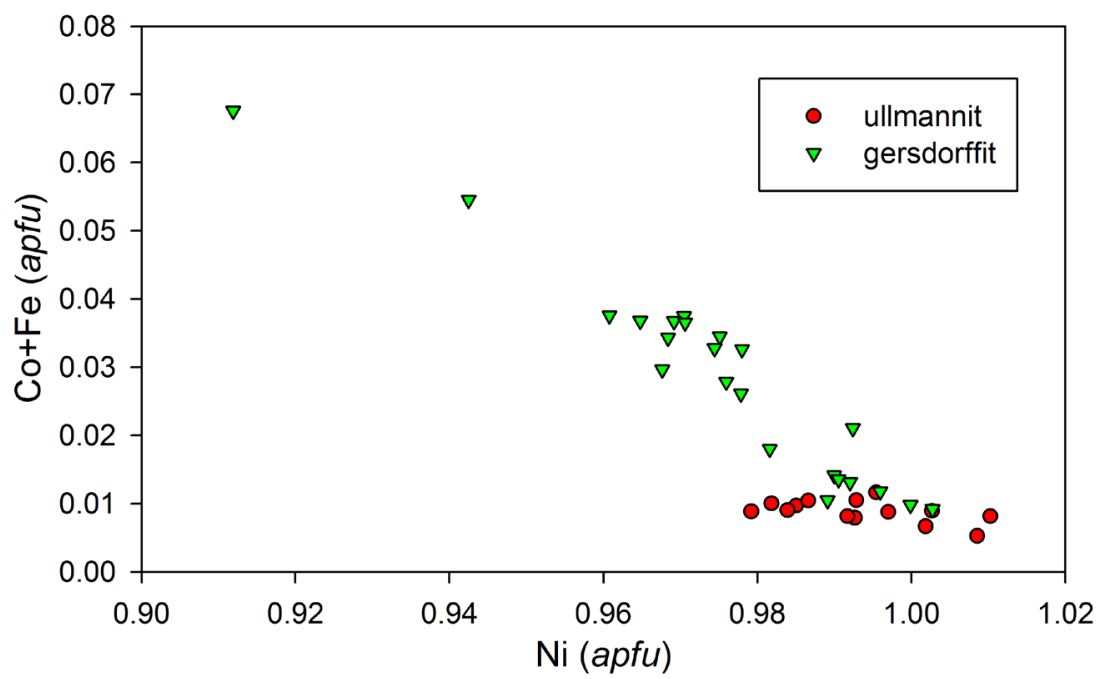

Obr. 8 Graf Ni vs. Co+Fe (apfu) pro minerály řady ullmannit - gersdorffit.

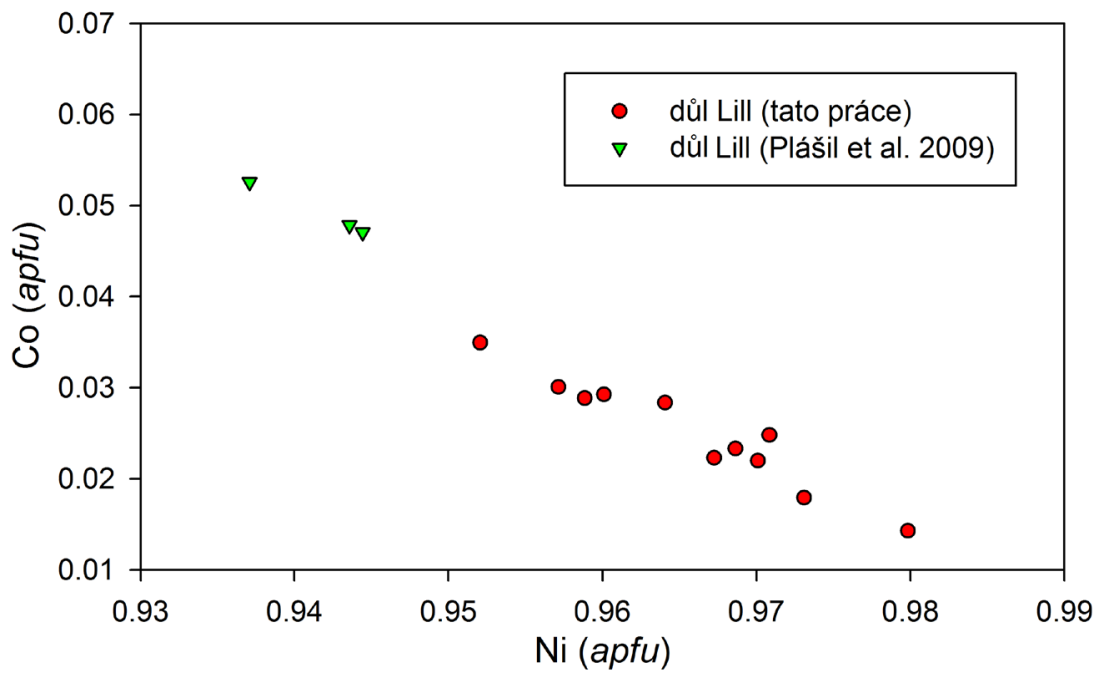

Obr. 9 Graf Ni vs. Co (apfu) pro millerit z haldy dolu Lill.
Nikon DXM1200.

Chemické složení mineralizace bylo kvantitativně studováno pomocí elektronového mikroanalyzátoru Cameca SX100 (Národní muzeum, Praha, analytik Jiří Sejkora) za podmínek: vlnově disperzní analýza, napětí $25 \mathrm{kV}$, proud $20 \mathrm{nA}$, průměr svazku $0.7 \mu \mathrm{m}$, standardy a použité analytické čáry: Ag (AgL $\alpha)$, apatit (CaKa, $\mathrm{PK \alpha}$ ), $\mathrm{Au}$ (AuMa), baryt (BaL $\alpha$ ), $\mathrm{Bi}_{2} \mathrm{Se}_{3}(\mathrm{BiM} \beta), \quad \mathrm{CdTe}(\mathrm{CdL} \alpha)$, Co (CoKa), $\mathrm{CuFeS}_{2}$ (CuKa, SKa), $\mathrm{FeS}_{2}$ (FeKa), GaAs (GaL $\alpha$ ), Ge (GeLa), HgTe (HgLa), InAs (InL $\alpha), \quad M n$ (MnKa), $\mathrm{NaCl}(\mathrm{ClK} \alpha), \mathrm{NiAs}(\mathrm{AsL} \beta), \mathrm{Ni}$ (NiKa), PbS (PbMa), PbSe (SeL $\beta$ ), $\mathrm{PbTe}(\mathrm{TeL} \alpha)$, sanidin $(\mathrm{KK \alpha}), \mathrm{Sb}_{2} \mathrm{~S}_{3}$ (SbLa), Sn (SnLa) a ZnS (ZnKa). Obsahy výše uvedených prvků, které nejsou zahrnuty $v$ tabulkách, byly kvantitativně analyzovány, ale zjištěné obsahy byly pod detekčním limitem (cca 0.03 - $0.05 \mathrm{hm}$. \% pro jednotlivé prvky). Získaná data byla korigována za použití softwaru PAP (Pouchou, Pichoir 1985).

Monokrystalová data byla získána pomocí rentgenového monokrystalového difraktometru Rigaku SuperNova vybaveného CCD detektorem Atlas S2, za použití intenzívního monochromatizovaného MoKa záření z mikrofokusní rentgenové lampy. Mřižkové parametry minerálu řady ullmannit - gersdorffit byly zpřesněny na základě 82 monokrystalových reflexí pomocí programu CrysAlis (Rigaku, 2020). Prášková data byla získána pomocí téhož difraktometru na identickém krystalu, a to pseudoGandolfiho metodou. Vzhledem k nepřesnosti metody nebyly mřižkové parametry zpřesňovány a jsou uvedeny pouze pozice difrakčních maxim a vizuálně odhadované intenzity.

\section{Charakteristika mineralizace}

Studovaný vzorek je tvořen hrubozrnným hnědým sideritem, který je protnut žilou bílého karbonátu o mocnosti až $1 \mathrm{~cm}$. V karbonátu zarůstají červené krystaly sfaleritu do velikosti $2 \mathrm{~mm}$, kulovité agregáty pyritu skládající se z drobných kubických krystalů a také vějiŕovité agregáty miIleritu o velikosti až $4 \mathrm{~mm}$. Agregáty milleritu jsou od okrajů zatlačovány drobnými, kovově šedými krystaly řady ullmannit - gersdorffit (obr. 1).

Minerály řady ullmannit - gersdorffit vytvářejí skupiny kovově šedých idiomorfních krystalů o velikosti do $0.5 \mathrm{~mm}$ narůstajících na krystaly milleritu (obr. 2); v odraženém světle jsou namodrale šedé $s$ nevýraznou anizotropií a je zřejmé, že starší agregáty milleritu částečně zatlačují (obr. 
Tabulka 1 Chemické složení ullmannitu z haldy dolu Lill, Příbram (hm. \%)

\begin{tabular}{|c|c|c|c|c|c|c|c|c|c|c|c|c|c|c|}
\hline & 1 & 2 & 3 & 4 & 5 & 6 & 7 & 8 & 9 & 10 & 11 & 12 & 13 & 14 \\
\hline $\mathrm{Ni}$ & 30.08 & 30.52 & 30.79 & 30.09 & 30.24 & 29.83 & 30.50 & 29.97 & 29.58 & 30.11 & 30.64 & 31.17 & 30.83 & 30.52 \\
\hline Co & 0.17 & 0.22 & 0.27 & 0.26 & 0.27 & 0.33 & 0.29 & 0.32 & 0.29 & 0.30 & 0.35 & 0.30 & 0.39 & 0.35 \\
\hline $\mathrm{Sb}$ & 40.02 & 36.68 & 35.43 & 35.01 & 34.70 & 34.26 & 33.21 & 33.12 & 33.07 & 32.77 & 32.54 & 32.57 & 32.52 & 31.89 \\
\hline As & 12.25 & 15.31 & 16.01 & 16.64 & 16.99 & 17.73 & 17.88 & 17.87 & 18.07 & 18.63 & 18.56 & 18.81 & 18.80 & 19.44 \\
\hline$S$ & 16.57 & 16.92 & 16.80 & 16.76 & 16.90 & 16.71 & 16.92 & 16.95 & 16.75 & 16.94 & 17.14 & 17.13 & 17.10 & 17.12 \\
\hline total & 99.09 & 99.65 & 99.30 & 98.76 & 99.10 & 98.86 & 98.80 & 98.23 & 97.76 & 98.75 & 99.23 & 99.98 & 99.64 & 99.32 \\
\hline $\mathrm{Ni}$ & 1.009 & 1.002 & 1.010 & 0.993 & 0.992 & 0.982 & 0.997 & 0.985 & 0.979 & 0.984 & 0.993 & 1.003 & 0.995 & 0.987 \\
\hline Co & 0.005 & 0.007 & 0.008 & 0.008 & 0.008 & 0.010 & 0.009 & 0.010 & 0.009 & 0.009 & 0.010 & 0.009 & 0.012 & 0.010 \\
\hline $\mathrm{Ni}+\mathrm{Co}$ & 1.014 & 1.009 & 1.018 & 1.001 & 1.000 & 0.992 & 1.006 & 0.995 & 0.988 & 0.993 & 1.003 & 1.012 & 1.007 & 0.997 \\
\hline $\mathrm{Sb}$ & 0.647 & 0.581 & 0.561 & 0.557 & 0.549 & 0.544 & 0.523 & 0.525 & 0.528 & 0.516 & 0.508 & 0.505 & 0.506 & 0.497 \\
\hline As & 0.322 & 0.394 & 0.412 & 0.430 & 0.437 & 0.457 & 0.458 & 0.460 & 0.469 & 0.477 & 0.471 & 0.474 & 0.476 & 0.492 \\
\hline $\mathrm{Sb}+\mathrm{As}$ & 0.969 & 0.974 & 0.972 & 0.987 & 0.985 & 1.001 & 0.982 & 0.985 & 0.997 & 0.993 & 0.980 & 0.979 & 0.982 & 0.990 \\
\hline$S$ & 1.017 & 1.017 & 1.009 & 1.012 & 1.015 & 1.007 & 1.013 & 1.020 & 1.015 & 1.014 & 1.017 & 1.009 & 1.011 & 1.013 \\
\hline
\end{tabular}

Tabulka 2 Chemické složení gersdorffitu z haldy dolu Lill, Přibram (hm. \%)

\begin{tabular}{|c|c|c|c|c|c|c|c|c|c|c|c|c|c|c|}
\hline & 1 & 2 & 3 & 4 & 5 & 6 & 7 & 8 & 9 & 10 & 11 & 12 & 13 & 14 \\
\hline $\mathrm{Fe}$ & 0.00 & 0.00 & 0.00 & 0.00 & 0.11 & 0.15 & 0.00 & 0.00 & 0.25 & 0.25 & 0.07 & 0.26 & 0.38 & 0.38 \\
\hline $\mathrm{Ni}$ & 30.48 & 31.09 & 31.21 & 31.02 & 31.68 & 31.81 & 32.23 & 32.34 & 32.34 & 32.18 & 32.11 & 31.23 & 32.92 & 32.14 \\
\hline Co & 0.35 & 0.33 & 0.40 & 0.48 & 1.02 & 1.16 & 0.64 & 0.48 & 0.65 & 0.95 & 1.28 & 2.21 & 0.91 & 1.58 \\
\hline $\mathrm{Sb}$ & 31.60 & 30.65 & 29.54 & 28.89 & 20.66 & 18.41 & 18.50 & 18.02 & 14.67 & 14.75 & 12.90 & 10.21 & 8.12 & 7.12 \\
\hline As & 9.52 & 19.48 & 21.02 & 21.28 & 28.58 & 29.94 & 30.42 & 30.15 & 33.13 & 33.42 & 35.23 & 39.33 & 38.80 & 40.49 \\
\hline S & 16.99 & 17.39 & 17.32 & 17.44 & 17.52 & 18.00 & 17.98 & 17.94 & 18.01 & 18.06 & 18.06 & 18.27 & 18.17 & 18.10 \\
\hline total & 98.94 & 98.94 & 99.49 & 99.11 & 99.57 & 99.47 & 99.77 & 98.93 & 99.05 & 99.61 & 99.65 & 101.51 & 99.30 & 99.81 \\
\hline $\mathrm{Fe}$ & .000 & 0.000 & 0.000 & 0.000 & 0.004 & 0.005 & 0.000 & 0.000 & 0.008 & 0.008 & 0.002 & 0.008 & 0.012 & 0.012 \\
\hline $\mathrm{Ni}$ & 0.989 & 1.000 & 0.996 & 0.990 & 0.978 & 0.970 & 0.982 & 0.991 & 0.978 & 0.968 & 0.9 & & 0.971 & 0.942 \\
\hline Co & 0.010 & 0.010 & 0.012 & 0.014 & 0.029 & 0.033 & 0.018 & 0.014 & 0.018 & 0.026 & 0.035 & 0.060 & 0.025 & 0.043 \\
\hline $\mathrm{Fe}+\mathrm{Ni}+\mathrm{Co}$ & 1.000 & 1.010 & 1.008 & 1.004 & 1.011 & 1.008 & 1.000 & 1.004 & 1.004 & 1.003 & 0.998 & 0.980 & 1.007 & 0.997 \\
\hline $\mathrm{Sb}$ & 0.494 & 0.475 & 0.455 & 0.445 & 0.308 & 0.271 & 0.272 & 0.266 & 0.214 & 0.214 & 0.186 & & 0.115 & 0.101 \\
\hline As & 0.496 & 0.491 & 0.526 & 0.532 & 0.691 & 0.716 & 0.726 & 0.724 & 0.785 & 0.788 & 0.826 & 0.900 & 0.896 & 0.930 \\
\hline $\mathrm{Sb}+\mathrm{As}$ & 0.991 & 0.966 & 0.980 & 0.977 & 0.999 & 0.987 & 0.998 & 0.990 & 0.999 & 1.002 & 1.012 & 1.044 & 1.012 & 1.031 \\
\hline$S$ & 1.010 & 1.024 & 1.012 & 1.019 & 0.990 & 1.005 & 1.003 & 1.006 & 0.997 & 0.995 & 0.989 & 0.977 & 0.981 & 0.972 \\
\hline
\end{tabular}

3 a 4). Srostlice krystalů jsou zřetelně sektorově zonální (obr. 2 a 5); světlé zóny jsou v BSE obraze představovány As-bohatým ullmannitem, převládající tmavší pak gersdorffitem s variabilními obsahy $\mathrm{Sb}$. Pro chemické složení ullmannitu jsou charakteristické vysoké obsahy As v rozmezí 0.32 - 0.49 apfu (obr. 6), současně praktická absence (As+Sb)S izomorfie (obr. 7) a jen zcela minimální obsahy Co (obr. 8). Jednotlivé bodové analýzy a odpovídající koeficienty empirických vzorců jsou uvedeny $v$ tabulce 1. Zjištěné rozsahy izomorfního zastupování v jednotlivých strukturních pozicích gersdorffitu jsou zřetelnější (tab. 2). Nalezené obsahy Sb se pohybují v rozmezí 0.10 - 0.49 apfu (obr. 6) a $S$ je v nevelkém rozsahu zastupována As+Sb (obr. 7). V kationtu (obr. 8) je dominantní $\mathrm{Ni}$ částečně substituován Co (do 0.06 apfu) a Fe (do $0.01 \mathrm{apfu}$ ); obsahy Co i $\mathrm{Fe}$ současně pozitivně korelují s obsahem As.

Rentgenová prášková data jsou uvedena v tabulce 3 , zpřesněný (na základě monokrystalových dat) mřížkový parametr a objem základní buňky studovaného krystalu
Tabulka 3 Práškový záznam minerálu řady ullmannit gersdorffit z dolu Lill (hodnoty $d_{\text {obs }}$ jsou udány $v$ A; relativní intenzity jsou stanoveny vizuálně)

\begin{tabular}{rrrrr}
\hline$d_{\text {obs }}$ & $l_{\text {rel. }}$ & $h$ & $k$ & $l$ \\
\hline 4.08 & 5 & 1 & 1 & 0 \\
3.31 & 25 & 1 & 1 & 1 \\
2.87 & 30 & 2 & 0 & 0 \\
2.58 & 55 & $\left\{\begin{array}{l}2 \\
2\end{array}\right.$ & 1 & 0 \\
2.35 & 100 & 2 & 1 & 1 \\
2.04 & 20 & 2 & 2 & 0 \\
1.74 & 50 & 3 & 1 & 1 \\
1.60 & 15 & 2 & 2 & 2 \\
1.54 & 20 & 3 & 2 & 1 \\
1.26 & 10 & 3 & 1 & 2 \\
1.02 & 12 & 4 & 2 & 1 \\
& & 4 & 4 & 0 \\
\hline
\end{tabular}


Tabulka 4 Mř́žkové parametry minerálů řady ullmannit - gersdorffit

\begin{tabular}{lllc}
\hline minerál (reference) & chemické složení & $a(\AA)$ & $V\left(\AA^{3}\right)$ \\
\hline gersdorffit-ullmannit (tato práce) & - & $5.7728(13)$ & $192.37(7)$ \\
gersdorffit (Bayliss, Stephenson 1967) & $\mathrm{NiAsS}$ & 5.6885 & 184.07 \\
gersdorffite, synt. (Foecker, Jeitschko 2001) & $\mathrm{NiAsS}$ & 5.6883 & 182.12 \\
ullmannite, synt. (Foecker, Jeitschko 2001) & $\mathrm{NiSbS}$ & 5.9339 & 207.66 \\
Co-ullmannite (Pratt, Bayliss 1980) & $\left.\left(\mathrm{Ni}_{0.86} \mathrm{Co}_{0.14}\right) \mathrm{SbS}_{2.03}\right)\left(\mathrm{Sb}_{0.91} \mathrm{As}_{0.08} \mathrm{Bi}_{0.01}\right)\left(\mathrm{S}_{0.98} \mathrm{As}_{0.02}\right)$ & 5.9218 & 184.06 \\
As-ullmannite (Bayliss 1977) & $\left(\mathrm{Ni}_{0.97} \mathrm{Co}_{0.03}\right.$ & 203.92 \\
\hline
\end{tabular}

Tabulka 5 Chemické složení milleritu z haldy dolu Lill, Přibram (hm. \%)

\begin{tabular}{|c|c|c|c|c|c|c|c|c|c|c|c|c|}
\hline & mean & 1 & 2 & 3 & 4 & 5 & 6 & 7 & 8 & 9 & 10 & 11 \\
\hline $\mathrm{Ni}$ & 63.17 & 63.18 & 62.76 & 63.34 & 62.64 & 62.45 & 63.14 & 64.05 & 63.31 & 63.75 & 63.31 & 62.99 \\
\hline Co & 1.78 & 1.55 & 2.07 & 1.65 & 2.13 & 2.48 & 2.01 & 1.01 & 1.75 & 1.27 & 1.58 & 2.05 \\
\hline $\mathrm{S}$ & 36.06 & 35.85 & 36.08 & 36.00 & 36.20 & 36.29 & 36.04 & 35.91 & 35.77 & 36.10 & 36.12 & 36.32 \\
\hline total & 101.01 & 100.58 & 100.91 & 100.99 & 100.97 & 101.22 & 101.19 & 100.97 & 100.83 & 101.12 & 101.01 & 101.36 \\
\hline $\mathrm{Ni}$ & 0.966 & 0.970 & 0.960 & 0.969 & 0.957 & 0.952 & 0.964 & 0.980 & 0.971 & 0.973 & 0.967 & 0.959 \\
\hline Co & 0.025 & 0.022 & 0.029 & 0.023 & 0.030 & 0.035 & 0.028 & 0.014 & 0.025 & 0.018 & 0.022 & 0.029 \\
\hline $\mathrm{Ni}+\mathrm{Co}$ & 0.991 & 0.992 & 0.989 & 0.992 & 0.987 & 0.987 & 0.992 & 0.994 & 0.996 & 0.991 & 0.990 & 0.988 \\
\hline$S$ & 1.009 & 1.008 & 1.011 & 1.008 & 1.013 & 1.013 & 1.008 & 1.006 & 1.004 & 1.009 & 1.010 & 1.012 \\
\hline
\end{tabular}

mean - průměr 11 bodových analýz; koeficienty empirických vzorců počitány na bázi 2 apfu.

Tabulka 6 Chemické složení siegenitu z haldy dolu Lill, Příbram (hm. \%)

\begin{tabular}{|c|c|c|c|c|c|c|c|c|c|c|}
\hline & mean & 1 & 2 & 3 & 4 & 5 & 6 & 7 & 8 & 9 \\
\hline $\mathrm{Fe}$ & 0.34 & 0.00 & 0.00 & 1.05 & 0.97 & 1.00 & 0.00 & 0.00 & 0.00 & 0.00 \\
\hline $\mathrm{Ni}$ & 31.81 & 32.89 & 32.49 & 30.56 & 30.44 & 30.53 & 32.33 & 32.32 & 32.10 & 32.65 \\
\hline Co & 25.68 & 25.65 & 25.61 & 25.86 & 26.02 & 25.91 & 25.79 & 25.52 & 25.58 & 25.17 \\
\hline S & 42.81 & 43.09 & 43.02 & 42.87 & 42.76 & 42.79 & 42.72 & 42.54 & 42.74 & 42.74 \\
\hline total & 100.63 & 101.63 & 101.12 & 100.34 & 100.19 & 100.23 & 100.84 & 100.38 & 100.42 & 100.56 \\
\hline $\mathrm{Fe}$ & 0.018 & 0.000 & 0.000 & 0.058 & 0.053 & 0.055 & 0.000 & 0.000 & 0.000 & 0.000 \\
\hline $\mathrm{Ni}$ & 1.658 & 1.699 & 1.686 & 1.596 & 1.593 & 1.596 & 1.684 & 1.691 & 1.677 & 1.704 \\
\hline Co & 1.237 & 1.224 & 1.228 & 1.248 & 1.258 & 1.252 & 1.241 & 1.234 & 1.235 & 1.213 \\
\hline $\mathrm{Fe}+\mathrm{Ni}+\mathrm{Co}$ & 2.914 & 2.924 & 2.913 & 2.901 & 2.904 & 2.903 & 2.925 & 2.925 & 2.912 & 2.917 \\
\hline$S$ & 4.086 & 4.076 & 4.087 & 4.099 & 4.096 & 4.097 & 4.075 & 4.075 & 4.088 & 4.083 \\
\hline
\end{tabular}

mean - průměr devíti bodových analýz; koeficienty empirických vzorců počítány na bázi 7 apfu.

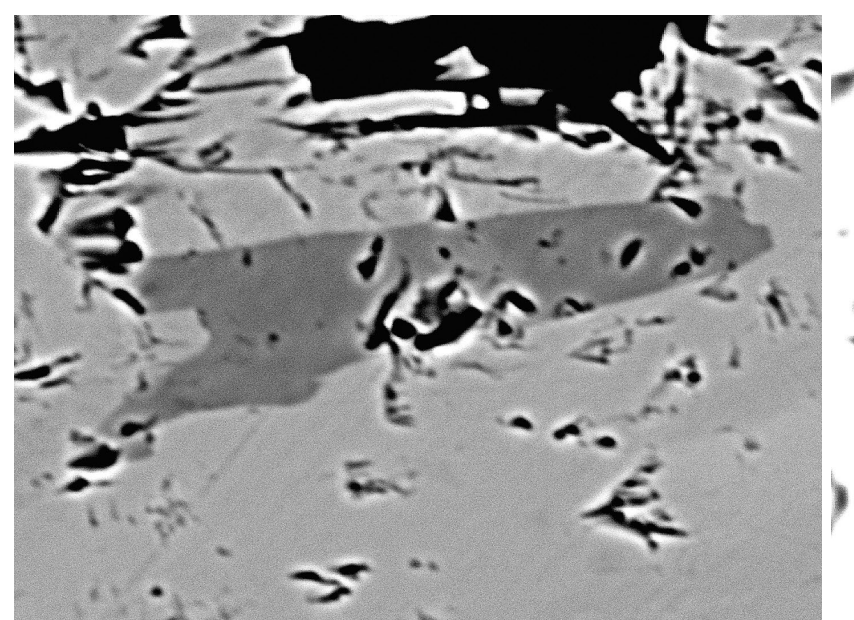

Obr. 10 Protáhlý agregát siegenitu (tmavěji šedý) zarůstající v milleritu (tmavě šedý), šířka záběru $100 \mu m$; BSE foto J. Sejkora.

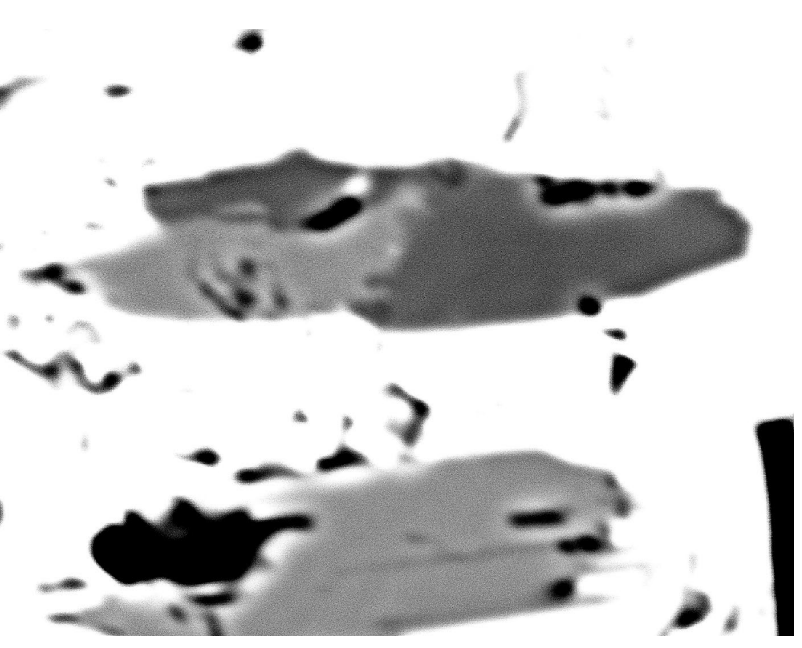

Obr. 11 Protáhlý agregát siegenitu (tmavě šedý) uzavřený spolu s milleritem (světle šedý) v ullmannitu - gersdorffitu (bilé), šiřka záběru $60 \mu \mathrm{m}$; BSE foto J. Sejkora. 
odpovídá přechodnému členu pevného roztoku ullmannit-gersdorffit a hodnoty nasvědčují, že studovaný krystal spíše odpovídá členům s dominantní gersdorffitovou komponentou (tab. 4).

Millerit vytváří na vzorku skupiny jehlicovitých krystalů o délce do $4 \mathrm{~mm}$, lokálně obrůstané a zatlačované minerály řady ullmannit - gersdorffit (obr. 1 - 5). Jeho chemické složení (tab. 5) je relativně jednoduché; v kationtu je převládající Ni v malém rozsahu (0.01 - 0.03 apfu) zastupován Co (obr. 9); zjištěné obsahy Co jsou nižší než uvádí pro millerit z haldy dolu Lill Plášil et al. (2009a). Jeho empirický vzorec (průměr 11 bodových analýz) je možno na bázi 2 apfu vyjádřit jako $\left(\mathrm{Ni}_{0.97} \mathrm{Co}_{0.03}\right)_{\Sigma 1.00} \mathrm{~S}_{1.01}$.

Ojediněle byly ve studovaném materiálu zjištěny velmi malé protáhlé agregáty siegenitu zarůstající do milleritu (obr. 10) nebo spolu s milleritem do agregátů minerálů řady ullmannit - gersdorffit (obr. 11). Chemické složení siegenitu (tab. 6) se od ideálního vzorce $\mathrm{CoNi}_{2} \mathrm{~S}_{4}$ odlišuje nižším zastoupením Ni (1.59 - 1.70 apfu) kompenzovaným obsahy Co (1.21 - 1.26 apfu) a lokálně Fe (do 0.06 apfu). Široká izomorfie je pro minerály skupiny linnéitu obvyklá (např. Litochleb et al. 2002). Empirický vzorec siegenitu (průměr devíti bodových analýz) je možno na bázi 7 apfu uvést jako $\mathrm{Co}_{1.00}\left(\mathrm{Ni}_{1.66} \mathrm{Co}_{0.24} \mathrm{Fe}_{0.02}\right)_{\Sigma 1.92} \mathrm{~S}_{4.09}$.

\section{Závěr}

Zjištěný výskyt minerálů řady ullmannit - gersdorffit v asociaci $s$ milleritem a siegenitem rozšiřuje informace $o$ primárních minerálech niklu z oblasti černojamského ložiska v březohorském rudním revíru, které je charakteristické zejména historickými ukázkami nikelínu a milleritu. Výskyt ullmannitu jako minerálu s významným obsahem Sb nebyl dosud znám ze žádné lokality celé příbramské rudní oblasti.

\section{Poděkování}

Milou povinností autorů je poděkovat Zdeňku Dolníčkovi a Janě Ulmanové z Národního muzea v Praze za spolupráci prí laboratorním výzkumu. Předložená práce vznikla za finančni podpory Ministerstva kultury ČR $v$ rámci institucionálního financování dlouhodobého koncepčního rozvoje výzkumné organizace Národní muzeum (DKRVO 2019-2023/1.II.b, 00023272).

\section{Literatura}

BABÁNek F A Kolektiv (1875) Der Silber und Blei Bergbau in Príbram. Wien: $144 \mathrm{~s}$

Bambas J (1990) Březohorský rudní revír. Symp Horn Příbram ve vědě a techn. Kamenná: $198 \mathrm{~s}$

BAYLISS P (1977) Crystal structure refinement of arsenian ullmannite. Am Mineral 62: 369-373

BAyliss P, StePHENSON N C (1967) The crystal structure of gersdorffite. Mineral Mag 36: 38-42

Foecker A J, JeitschKo W (2001) The atomic order of the pnictogen and chalcogen atoms in equiatomic ternary compounds TPnCh ( $T=\mathrm{Ni}, \mathrm{Pd}$; $\mathrm{Pn}=\mathrm{P}, \mathrm{As}, \mathrm{Sb}$; $\mathrm{Ch}=$ S, Se, Te). J Solid State Chem 162: 69-78
Litochleb J, SEJKora J, Šrein V (2002) Mineralogie stříbrného zrudnění z Brodu u Příbrami (příbramský uran -polymetalický revír). Bull mineral-petrolog Odd Nár Muz (Praha) 10: 221-234

Litochleb J, Sejkora J, Šrein V, Litochlebová E, Jindra J (2004) Magnetit a jeho postavení v paragenezích hydrotermálních žil příbramské rudní oblasti. Bull mineral -petrolog Odd Nár Muz (Praha) 12: 123-131

ONDRUŠ P, VESELOVSKÝ F, RYBKA R (1990) Znucalite, $\mathrm{Zn}_{12}\left(\mathrm{UO}_{2}\right) \mathrm{Ca}\left(\mathrm{CO}_{3}\right)_{3}(\mathrm{OH})_{22} \cdot 4 \mathrm{H}_{2} \mathrm{O}$, a new mineral from Príbram, Czechoslovakia. N Jb Mineral, Mh 9: 393400

PlášIl J, Sejkora J, Litochleb J, Goliáš V (2005) Nález minerálu blízkého andoritu (tzv. „Minéral F“) v asociaci s diaforitem a dalšími minerály $\mathrm{Pb}-\mathrm{Ag}-\mathrm{Sb}$ na haldě dolu Lill (Černojamské ložisko), Příbram. Bull mineral -petrolog Odd Nár Muz (Praha) 13: 187-192

PLAšIL J, SEJKoRA J, LITOCHLEB J (2007) Makroskopický semseyit z haldy dolu Lill (Černojamské ložisko), Př́bram. Bull mineral-petrolog Odd Nár Muz (Praha) 1415: $92-95$

PLÁšIL J, SEJKora J, Litochleb J (2009a) Siegenit a heazlewoodit $v$ asociaci s milleritem $z$ haldy dolu Lill (černojamské ložisko), Př́bram, Česká Republika. Bull mineral-petrolog Odd Nár Muz (Praha) 17(1): 101-104

PLÁšIL J, SEJKORA J, Litochleb J, ŠKÁCHA P (2009b) Výskyt vzácného Ag-Hg sulfidu - imiteritu - v materiálu z haldy dolu Lill (černojamské ložisko), březohorský rudní revír, Česká republika. Bull mineral-petrolog Odd Nár Muz (Praha) 17(2): 62-68

Pouchou JL, PICHOIR F (1985) "PAP" ( $\varphi \rho Z)$ procedure for improved quantitative microanalysis. In: Microbeam Analysis (J. T. Armstrong, ed.). San Francisco Press, San Francisco, 104-106

PRATT J L, BAYLISS P (1980) Crystal structure refinement of a cobaltian ullmannite. Am Mineral 65: 154-156

RIGAKu (2020) CrysAlis CCD and CrysAlis RED. Oxford Diffraction Ltd, Yarnton, Oxfordshire, U.K.

SeJkora J, ČERnÝ P, Černý P (2010) Výskyt vzácného seleničitanu, munakataitu, na haldě dolu Lill v Příbrami (Česká republika). Bull mineral-petrolog Odd Nár Muz (Praha) 18(2): 87-90

SeJkora J, Grey IE, Kampf AR, PLAšIL J, ŠKÁcha P (2019) Bouškaite, a new molybdenyl-hydrogensulfate mineral, $\left(\mathrm{MoO}_{2}\right)_{2} \mathrm{O}\left(\mathrm{SO}_{3} \mathrm{OH}\right)_{2}\left(\mathrm{H}_{2} \mathrm{O}\right)_{2} \cdot 2 \mathrm{H}_{2} \mathrm{O}$, from the Lill mine, Príbram ore area, Czech Republic. J Geosci 64(3): 197-205

ŠKÁCHA P, PLÁ̌IL J (2002) Minerály Březohorského rudního revíru. Bull mineral-petrolog Odd Nár Muz (Praha) 10: 43-77

ŠKUBAL P, JANOUT T (1965) Závěrečná zpráva o výsledcích geologicko-průzkumných prací $v$ lillském revíru. MS Diamo SUL. Príbram: 176 s 